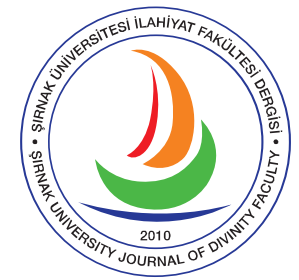

\title{
Yeni Bir İslami Edebiyat Teorisi Doğrultusunda Evrensellik
} Universality Towards A New Theory of Islamic Literature

\section{Arif Karkhi ABUKHUDAİRI}

Doç. Dr., Sultan Şerif Ali İslam Üniversitesi, Arap Dili Bölümü

Associate Professor Dr, Sultan Sharif Ali Islamic University, Department of Arabic

$$
\text { Language }
$$

Darusselam, Brunei

arif.abukhudairi@unissa.edu.bn

\section{Çeviren/Translated by}

Nesrin Aydın Satar

Arş. Gör., Ankara Üniversitesi, İlahiyat Fakültesi, Türk İslam Edebiyatı Ana Bilim Dalı

Research Assisstant, Ankara University, Faculty of Divinity, Department of Turkish İslamic Literature

Ankara, Turkey

nesrin.satar@gmail.com

https://orcid.org/0000-0003-0559-9983

\section{Makale Bilgisi / Article Information}

Makale Türü / Article Types: Çeviri / Translation

Geliş Tarihi / Received: 30 Ağustos / August 2019

Kabul Tarihi / Accepted: 7 Kasim / November 2019

Yayın Tarihi / Published: 15 Aralık / December 2019

Cilt / Volume: 10 Sayı / Issue: 23 Sayfa / Pages: 825-843

Atıf / Cite as: Abukhudairi, Arif Karkhi. "Yeni Bir İslami Edebiyat Teorisi Doğrultusunda Evrensellik [Universality Towards A New Theory of Islamic Literature]". Çev. Nesrin Aydın Satar. Şırnak Üniversitesi İlahiyat Fakültesi Dergisi - Şırnak University Journal of Divinity Faculty 10/23 (December 2019): 825-843.

https://doi.org/10.35415/sirnakifd.613301

Copyright (C) Published by Şırnak Üniversitesi, İlahiyat Fakültesi / Şırnak, Türkiye (Şırnak University, Faculty of Divinity, Şırnak, 73000 Turkey). 
Öz

20. yüzyıl ortalarında, Ortadoğu ve özellikle Mısır'da İslami yazar ve entelektüeller etkin bir şekilde İslami edebiyatı isimlendirmekle meşguldüler. Bu konuda aralarında Seyyid Kutub, Muhammed Kutub ve Nejib elKilani'nin başlıca eserleri de bulunan birçok Arapça kitap kaleme alındı ve Malayca ve Endonezce dillerine çevrildi. Tüm bu eserler arasında, Muhammed Kutub'un İslam Düşüncesinde Sanat isimli kitabının Ahmed Kemal Abdullah, Şahnun Ahmed, Muhammed Kemal Hasan, İsmail İbrahim, Muhammed Buhari Lubis ve İslami edebiyat teorisi üreten diğer Malay yazarları üzerinde muazzam bir etkisi oldu. Bu makalede, "evrensellik" (el-'âlemiyye) kavramına dayanan yeni bir İslami edebiyat teorisi önerilir. Makalenin birinci kısmında mevcut teoriler gözden geçirilirken sonuç kısmında İslami edebiyat kavramı, mesajı ve İslami edebiyatı diğer dünya edebiyatlarından ayıran yedi temel özellik gibi birçok konu tartışılır.

Anahtar Kelimeler: Türk İslam Edebiyatı, Evrensellik, Edeb, İslam, Müslüman, İslami.

\begin{abstract}
In the middle of the 20th century, Islamic writers and intellectuals in the Middle East and particularly in Egypt were actively engaged in the call for Islamic literature. Several Arabic books, including major works of Sayyed Qutub, Muhammad Qutub, and Naguib Kilani, were written on the subject and immediately rendered into Malaysian and Indonesian languages. Among all these writings, Muhammad Qutub's book "Manhaj El-Fan ElIslami" has had tremendous impact on modern Malay writers such as, Ahmad Kamal Abdullah, Shahnon Ahmad, Muhammad Kamal Hassan, Ismail Ibrahim, Muhammad Bukhari Lubis, and others who produced several theories of Islamic literature. In this paper, a new theory of Islamic literature is proposed which is based on the concept of Al-'Alamiah (Universality).In the first part of the paper, existing theories are reviewed whereas in the final part, a number of issues are discussed such as the concept of Islamic literature, its message, and seven basic features that distinguish Islamic literature from other world literatures.
\end{abstract}

Keywords: Turkish Islamic Literature, Alamiah, Adab, Islami, Muslim, Islamic. 


\section{GİRIŞ ${ }^{1}$}

XIX. ve XX. yüzyıllarda Müslüman dünyadaki çöküş, işgal, batılılaşma, laiklik, sapkınlık, şüphecilik, komünizm, sanat sanat içindir gibi olgular; Müslüman entelektüel ve yazarları tüm bu tehlikelerle çarpışmak ve birçok politik, ekonomik, sosyal ve sanatsal problemin üstesinden gelmek için İslam'ın ilkelerine geri dönmeye çağırmıştır. Bahsi geçen durumlar birçok Müslüman düşünür ve yazar1-19.yüzyılın ortasından itibaren- İslami edebiyatın isimlendirilmesiyle meşgul etmiştir. Söz konusu düşünür ve yazarlardan bazıları İslami edebiyat isimlendirmesini destekleyebilecek ve bu edebiyatı tenkit etmek için kullanılabilecek yeni bir teori tanımlamaya çalıştılar.

\section{1. İSLAMİ EDEBİYAT TEORİSİ}

Müslüman dünyada birçok İslami edebiyat teorisi bulunmaktadır ancak bu makale yalnızca, modern Müslüman düşünür ve yazarlar tarafından önerilen en önemli teoriler olduğunu düşündüğüm dört teoriden bahsedecektir. Bunlar; Şahnun Ahmed'in İbadet Teorisi (Theory of Worship,1977), Muhammed Kemal Hasan'ın Bağlanmış edebiyat (Literatüre engageé, 1977), İsmail İbrahim'in Tevhid Teorisi (Theory of Tawhid, 1988) ve Şafi Ebubekir'in Tamamlayııı Teorisidir. (Tekmilah Theory, 1995). Bu teorisyenler, Malay üniversitelerinde profesör olarak çalışan akademisyenlerdir ve Şahnun Ahmed dişında hepsinin güçlü bir dini akademik geçmişleri vardır. Muhammed Kemal Hasan haricinde hepsi yaratıcı yazarlardır: Şahnun Ahmed ödüllü bir roman yazarı, İsmail İbrahim yetenekli bir hikâye yazarı ve Şafi Ebubekir ise tanınmış bir şairdir.

a. Şahnun Ahmed tarafından kurulan İbadet Teorisi "sanat sanat içindir" ve "sanat toplum içindir" şeklinde ifade edilen ve dolayısıyla edebiyatı dünyevî hususlarla ilişkilendiren Batılı teorilere bir reaksiyon olarak ortaya çıkmıştır. Şahnun Ahmed edebiyat ve din arasında bağlantı kurar ve edebiyatı Allah'tan bir hediye olarak görür. Ona göre, yazar edebiyatı bir ibadet şekli olarak düşünerek Allah'a bu hediye için minnettar olmalıdır. Edebiyat insanlara gerçeği anlamalarında yardım etmeli ve Allah'ın merhametini ararken onların ahlaklarını yükseltmelidir. Bunu başarmak için edebiyat, tevhit prensibine dayanmalı ve yazar, insanın rolünü Allah'ın

\footnotetext{
1 "Universality Towards A New Theory Of Islamic Literature", European Journal of Research and Reflection in Arts and Humanities 3/1 (2015): 34-47. Erişim 10 Temmuz 2019. https://www. idpublications.org/wp-content/uploads/2014/12/Universality-Towards-a-New-Theory-ofIslamic-Literature.pdf
} 
yeryüzündeki vekili olarak açıkça tasvir etmelidir. Dahası, yazar muazzam bir dini bilinç ile donanmış olmalı, sanatsal teknikleri uygulamalı ve seçkin edebi yazın kurallarında uzmanlaşmalıdır.

Şahnun Ahmed, edebiyatta dini bağımlılıklardan uzak olarak tasvir edilen yazar özgürlügüne inanır. Aynı zamanda yazar ne hakikatten ne de Allah'ın mesajından ayrılmalıdır. Başka bir deyişle, yazara göre edebiyat, yazarın açı hedefleri olmaksızın fantezileri ya da hevesleri hakkında değildir. Yazma kabiliyetini sahiplenme ve kullanma, yazarın İslami çerçeveyi ihmaliyle sonuçlanmamalıdır. Onları hakikate ulaştırması mümkün olan kendi hayal güçlerine sarılan Batılı yazarların aksine İslami yazarlar, hayal güçlerini hakikate doğru yöneltmelidirler.

Şahnun Ahmed İslami edebiyatın muğlak değil açık olmasına ve yazarların Hz. Muhammed'in izinden yürümesi gerektiğine inanır. Bu ise, insanlara zihinsel kapasitelerine göre hitap ederek ve her ifadenin belirli bir duruma münasip olmasıyla yapılabilir. Şahnun Ahmed yazarların edebiyatın hem şekline hem de içeriğine dikkat etmeleri gerektiğini düşünmesine rağmen onları kullandıkları güncel kelimelere daha fazla dikkat göstermeye çağırır. ${ }^{2}$

b.Muhammed Kemal Hasan iltizam (sözleşme, taahhüt, bağlanma/ engagement) kavramına odaklanır ve yazarların, bir yanda dine ve dinin gerçeklik ile ilgili görüşüne bağlanmaya ve öte yanda yeryüzünde Allah'ın vekili olma görevine dair söz verdikleri Bă̆lanmış edebiyat (literature engageé $)^{3}$ tanımını benimser. Kemal Hasan, İslami yazarların, insanları evrensel İslami ilkelere göre devletin ilerlemesi ve gelişmesine doğru itmesi gerektiğini ileri sürer.

Şahnun Ahmed gibi Kemal Hasan da edebiyatı din ile ilişkilendirir ve onu Allah'a itaat etmeye rehberlik eden bir yol olarak görür. Nitekim edebiyat Allah katında güzel kalmak için dini buyruklarla çelişmemelidir. Zaten ibadet eden kişi yaratıcısına itaatsiz olur ve onu inkâr ederse güzelliğe ulaşamaz. Kemal Hasan edebiyatı insanoğlunun hilafeti, itaatin güzelliği ve Allah'ı memnun eden değerler ve takva ile ilişkilendirir. İsla-

2 Bk. Rahmah BT Ahmad \& Adly Yaacob, Al-Islam Wal Al-Adab Al-Malayui (Kuala Lumpur: IIUM Press, 2008), 176-178, 199-200, 333-359.

3 Sartre'ın literature engageé kavramı ve kavram hakkında ayrıntılı bilgi için bk. Jean Paul Sartre, Edebiyat Nedir?, çev. Bertan Onaran (İstanbul: Can Yayınları, 2005). Terim hem bu çeviri kitapta hem de Aslı Uçar'a ait yüksek lisans tezinde bu şekilde Türkçe' ye çevrildiğinden kavram bu makalede de bağlanmııs edebiyat şeklinde kullanılmıştır. Bk. Aslı Uçar, 1950ler Türkiye'sinde Edebiyat Dergiciliği: Poetikalar ve Politikalar (Yüksek Lisans Tezi, Ankara: Bilkent Üniversitesi 2007). (Çevirenin notu) 
mi edebiyatın eğlence, zevk veya yaşamdaki ikincil konuları geliştirmeyi değil ancak yaşamı insanoğlunun görevine ve gerçek yerine layık, onurlu bir yer yapmayı amaçladığını düşünür. ${ }^{4}$

c.İsmail İbrahim, İslami edebiyatı tevhid (tektanrıcılık/monotheism) e dayanan bir yazma eylemi olarak tanımlar. Edebiyatlarının yazarların kendi fantezi ve arzularına değil gerçek İslami esasa dayanması için Allah'ın birliği iddiasında bulunan yazarlar, bunu İslam'ın kanonik yasalarına uyarak yansıtmalıdır. Böylece, edebi eserler Allah'ın dinine hizmet edeceklerdir. Tevhid ve $v a^{\prime} i$ (idrak) ${ }^{5}$ den başka İslami edebiyatın şekillenmesinde üçüncü bir önemli unsur daha vardır: İhlas (samimiyet). Bu yüzden İslami edebiyat sanatsal güzellik kadar, dini ve sosyal yönleri de içermelidir. Başka bir deyişle edebiyat; Allah'a inancı, onun tekliğini ve İslam'ı göstermek zorundadır. Aynı zamanda, gerçekçi sosyal meselelerle baş etmeli ve insanların ahlakları ve insanî değerlerle bağlantılı olmalıdır. Yani edebiyat hem akideyi (inanç/iman) hem de ahlakı içermelidir.

İsmail İbrahim, İslami edebiyatın okuyuculara adalet, eşitlik ve doğruluk gibi pozitif fikirleri ortaya çıkarmada yardımcı olması gerektiğini belirtir. Hakikat ve güzelliği İslami edebiyatın iki esas maddesi olarak ele alır. İslami yazarlar ün ve talih için edebiyat yapmazlar dolayısıyla sanatsal ifadeler saf ve iyi olan her şeyi içermelidir ki bu değerler aracılığıyla Allah'a bize ihsan ettiği nimetler için şükrümüzü gösterebilelim. Ayrıca insanın sanatsal ifadeleri ahlaki değerlere ve yüksek manevî meselelere odaklanmalıdır.

İsmail İbrahim için edebiyatın amacı, insanlığ takva ve iman seviyesine yükseltmektir. İsmail İbrahim'e göre, bu tarz bir edebiyatın toplum içinde çok önemli bir mesajı vardır çünkü takva ve imana değil yalnızca hayal gücü ve duygulara dayanan edebiyat kişinin dünyevî ve cinsel iştahını tatmin etmeyi amaçladığ i için güvenilmezdir. Böyle bir edebiyat sonunda; bireylerin yıkımına yol açacak, birçok sosyal probleme sebep olacak ve endişe, korku ve düzensizlik üretecektir.

İsmail İbrahim için edebiyat, güzellikle eş anlamlıdır. Edebiyat inananın kalbine, aklına ve inancına yakın olan ve kaynağını "gerçek yasa" dan ${ }^{6}$ alan hakikat ve adaletin güzelliğine dayanır. ${ }^{7}$

4 Ahmad v.dğr., Al-Islam Wal Al-Adab Al-Malayui, 154-156, 178-182, 204-217, 380.

5 Mevlût Sarı, El-Mevârid: Arapça- Türkçe Lûgat (İstanbul: Bahar Yayınları, 1980), 1669. (Çevirenin notu)

6 Metinde true principle kavramıyla karşılanan ifade, Kuran-1 Kerim'e gönderme yapmaktadir. (Çevirenin notu)

7 Ahmad v.dğr., Al-Islam Wal Al-Adab Al-Malayui, 170-172, 183-184, 390-391. 
d. Şafi Ebubekir İslami edebiyatı Müslüman yazarların hayat ve tevhit inanışı üzerine İslami bakışın derin anlayışından sızan bir ürün olarak görür ve bu edebiyat en güzel ifadeleri en güzel şekillerde kullanır. Dahası, Şafi İslami edebiyatın insanî, manevî, evrensel ve sanatsal unsurları içermesi gerektiğine inanır.

Şafi teorisini tamamlayıcı teori (tekmile/tekmilah) olarak adlandırır ve onu mükemmellik (el-kemal/perfection) ve güzellik (el-cemal/beauty) ile ilişkilendirir. Edebiyat bu ilkeleri bulmalı, sergilemeli ve de bütünleştirmelidir.

Şafi'ye göre, edebiyatın amacı yaratıcıyı yüceltmek ve İslam sevgisi ve merhamet aşılayarak insanı, mükemmellik seviyesine yükseltmektir. Yazar okuyucularına olumlu değerlerin artışı yönünde bilgece rehberlik etmelidir ve böylelikle muhataplar, İslam öğretilerinin gerektirdiği yol dâhilinde karakterlerini tamamlayabilirler.

Şafi İslami edebiyatın konularının tamamlayıcı teoriye uygun olduğu ölçüde İslami değerlerle bağlantılı olduğunu savunur.

Şafi, İslami yazarların İslam'ın temel prensiplerini tamamen anlayabilecekleri İslami bir eğitim geçmişine sahip olmaları ve akide, şeriat ve ahlakı bilmeleri gerektiğini söyler. Bunlara ek olarak, yazarlar İslam ve edebiyat konusunda bilgili olmalıdırlar çünkü bu bilgi olmadan okuyucularını mükemmelliğe götüren İslami edebi eserleri üretemezler.

Şafi'nin teorisi daha çok yüce değerlerle alakalıdır, hakikati ve güzeli vurgular ve tamamlayıcı teorinin ya da İslami edebiyatın doruk noktasına götüren bu iki değerin karışımını ele alır.

Şafi İslami edebiyatın amacının, topluma İslami değerlere ve onun gerçek öğretilerine dayanan doğru dürüst bir eğitim temin etmeyi sağlamak olduğunu düşünür. Dahası, edebiyat aracılığıyla yazarların, kendilerine ve topluma onları mükemmellik seviyesine yükselten değer ve düsturları sağladığını savunur.

Şafi ayrıca İslami yazarların, meyvelerini toplamak ve onun izinden gitmek için kendi görüşlerinden önce Kuran'ı esas almaları gerektiğini vurgular. Yazarlar ayrıca; peygamberin sözlerini, sahabelerinin ve takipçilerinin hikâyelerini ve önceki İslami yazarların eserlerini de önemsemelidirler. ${ }^{8}$

Yukarıda bahsedilen teoriler modern İslami edebiyat teorileri içinde en ünlü olanlarıdır. Tüm bu teoriler genel olarak, yalnızca İslam'la sınırla

8 Ahmad v.dğr., Al-Islam Wal Al-Adab Al- Malayui, 173, 192-196, 200-201, 251-293. 
olmayan, ayrıca diğer dinlerde de bulunabilecek ibadet, kulluk ve tevhit fikirlerine dayanır. Ayrıca bu teoriler edebi değil dini düşüncelere bağl1dır. Bazı teoriler yazarın özgürlüğünü kısıtlar ve bazıları da İslam ümmetinin ya da bütün insanlığın değil devletin refahının altını çizen sosyal ve gerçekçi teorileri kapsar. Bunlara ek olarak; bazı teoriler edebiyatın rolünden çok yazarın rolünü vurgular, bazıları ise sanatsal tarafları değil içeriği, biçimi değil konuyu ya da yöntemi veya usulü göz önüne alır.

Bütün bu teorilerin edebiyatı milliyetçilikle ilişkilendirdiği de görülür. Dahası, İslami edebiyat kavramı, ilerde de bahsedileceği gibi, İslami edebiyatın metodunu, mesajını ve İslam'da güzellik kavramını göz önüne almaları gerekmesine rağmen söz konusu teorisyenler tarafından tanımlandığı kadarıyla hem konu hem de bağlamla sınırlandırılmıştır.

Sonuç olarak, edebiyatla daha yakından bağlantılı olan ve İslam'ı, onun ruhunu ve yüce mesajını daha iyi yansıtan yeni bir İslami edebiyat teorisine ihtiyaç vardır. Bu sebeple, bu makale edebi bir terim olduğu kadar dinî de olan evrensellik (el-âlemiyye) kavramına dayanan yeni bir teori önerir. Makale; İslami edebiyat kavramı, içeriği, mesajı ve onu diğer dünya edebiyatlarından ayıran tarafları gibi bu teoriyle yakından alakalı olan birçok noktayı tartışır.

\section{EVRENSELLİK TEORİSI}

Bir kişi, Kur'an-1 Kerim'i yakından incelediğinde, "âlem" kelimesinin Fâtiha'daki "El-hamdu li'llâhi Rabbi'l âlemîn" ayetinde ve Bakara, En'âm, Yûnus, Yûsuf, Enbiyâ, Şuarâ ve Zuhruf gibi diğer birçok surede sık sik geçtiğini fark edecektir. Kelime "insanlık", "dünya", "evrensellik", "varlık" ve "evren" i de içiren birçok anlamda ortaya çıkar. Âlem kelimesi en başta yaratııı ile sonra onun son elçisi ve kutsal kitabı ile bağlantılıdır. Allah "Rabbi'l-âlemîn" (âlemlerin rabbi/lord of the worlds), Hz. Muhammed "Resûlu'l Rabbi'l-âlemîn" (âlemlerin rabbinin elçisi/messenger of the lord of worlds) ve Kuran "zikrun ve rahmetün lil âlemîn" (insanlığa uyarı ve rahmet/reminder and mercy for the mankind) olarak ifade edilir. Ve böylece İslam'ın hakikati tüm insanlık için evrensel bir din olarak vahyedilir.

Kur'an-1 Kerim yalnızca İslam'ın peygamberi ve Müslümanlar hakkında hikâyeler anlatmaz. Bunlar hakkında ve örneğin; inananlar, diğer dinlerden insanlar, inanmayalar ve birçok insan ve milletler hakkında da konuşur ve hem Müslümanlara hem de Müslüman olmayanlara hitap eder. Kendini bütün insanlara yöneltir.

İslam insanlığın dinidir. İnsanın pozisyonunu yüceltir ve onu varlı- 
ğın merkezi ve Allah'ın vekili yapar. Allah dünyayı insanlar için yaratmıs, onlara bütün dilleri öğretmiş ve onları yeryüzünde üstün kılmış, onlara nimetler ve hazineler bağışlamış ve insanları bütün dünyadan sorumlu kılmıştır. ${ }^{9}$

İslam tüm insanlığın tek ruhtan yapıldığ gerçeğini ve hepsinin topraktan yaratıldığını, bir anne ve bir babadan kız kardeş ve erkek kardeşler olduklarını, tarağın dişleri gibi eşit olduklarını ve Araplarla Arap olmayanlar, siyah ve beyaz, zengin ve fakir arasında hiçbir fark olmadığını vurgular. İslam insanları; kökenlerine, kanlarına, renklerine, ırklarına ve diğer yanlış ve yapay farklılıklara göre ayıran milliyetçilik, vatanseverlik, ırkçılık ve alansalcılık isimleriyle yükselen tüm çağrılara karşıdır.

Edebiyatın evrenselliği yalnızca o edebiyatın başka bir dilde yazılmış iken içinde yer aldığı dilden ayrı olabileceği anlamına gelmez, ayrıca bütün insanlığa yönelmiş edebiyat anlamına da gelir. ${ }^{10}$ Edebiyatın evrenselliği, milli sınırlardan ve yerel kapsamdan uzaktır ve tüm insanlar ve tüm mekânlarla ilişkilidir. Konuları tüm zamanlar ve tüm durumlar için geçerlidir ve tüm zevklere ve kültürlere uyar ve insanların özüyle ilgilidir.

Edebiyat, bütün edebiyatlar birbiriyle uyum sağladığı ve hepsi edebi türleri, sanatsal kökenleri ve insan hedeflerinde benzeştiği zaman evrensel olur. Böylelikle dil ve tikel bir bölgenin ya da çevrenin tikel bir yazara ilham verebilmesinden başka evrensel edebiyat için hiçbir engel olmayacaktır. ${ }^{11}$

Edebiyatın evrenselliği kavramı; yazar, okuyucu, konu, dil ve mesaj ile ilgilidir. Bundan sonra evrensellik kavramı; İslami edebiyat kavramı, bu edebiyatın özellikleri ve mesajına odaklanarak tartışılacaktır.

a. İslami edebiyat, Kur'an-1 Kerim ve Hadis'ten kaynağını alan İslam'1 anlamaya dayanır ve ilahiyat, peygamberlik, elçiler, melekler, kutsal kitaplar, ahiret, yeniden diriliş, kıyamet, kader, önceden tanımlanmış emirler ve insanların hayattaki rolü ve insanlık, yaratıcı ve tüm dünya ile ilişkileri gibi temel meselelerle ilgilidir.

İslam'ı anlamakla ilgili olan diğer meseleler bütün insanların aynı kökenden olduğu hakkındaki inanışa aittir: "Şüphesiz bu (insanlar) bir tek ümmet olarak sizin ümmetinizdir." (el-Mû'minûn, 23/52) ${ }^{12}$ ve böylelikle

9 Abul Hassan Al-Nadawi, Rawai' Iqbal (Damascus: Daru'l-Fikr, 1960), 78.

${ }^{10}$ Muhammad Ghunaimi Hilal, Al-Adab Al-Muqaran (Beirut: Dar Al' Awdah, 1982), 104.

${ }^{11}$ Hilal, Al-Adab Al-Muqaran, 288.

${ }_{12} \mathrm{Bu}$ ayet ve bundan sonraki ayetlerin mealleri için bk. Kuran-ı Kerim, Erişim: 03.07.19. https:// kuran.diyanet.gov.tr/mushaf/kuran-meal-2/fatiha-suresi-1/ayet-1/diyanet-isleri-baskanligimeali-1 (Çevirenin notu) 
tüm insanlar bir anne ve bir babaya aittir (Bütün insanlar Âdem'den gelmiş, Âdem de topraktan yaratılmıştır. $)^{13}$ ve Allah'ın gözünde hepsi eşittir.

İslam'ı anlamakla ilgili diğer meseleler; “Biz dünyada yaşıyoruz ve dünya da bizimle yaşıyor, dünya bizim göremediğimiz diğer dünyalarda da yaşıyor, dünyadaki diğer şeyler ve bizim aramızda hiçbir ayrım yok, her insan bünyesinde diğer insanları da taşıyor, özgürlük hayal gücünün kapsamını her şeyde ve herkeste kendini görme boyutuna doğru genişletmektir ve biz ve dünya bölünemez bir birlik oluştururuz." inancını içerir.

İslam'a göre insan hayatın merkezidir ki bu hayat bölünmez bir bütündür. Her insan; diğer insanları kendi bünyesinde taşır ve nereye giderse gitsin her gördügünde kendini bulur, her şey onunla birliktedir, bir zaman ya da bir mekânla kısıtlı değildir ve birçok insanın kalbine ektiği tohumların yetiştiğini görmekten ve meyvelerini toplamaktan hoşnut olur.

Dahası, İslam'da insan; birçok insan, mekân ve bilincinde veya bilinçdışında var olan ve kendileri ya da başkaları için yaşayan tüm bitkileri, böcekleri, kuşları, balıkları ve hayvanları kapsayan yaratıklara da görünmez bağlarla bağlıdır. Dolayısıyla hayat bireyin bütünü desteklemesi için yaratılmıştır ve yaşam özünde her zaman bir çoğunluk değil bir topluluk, bir grup, bir bütündür.

İslami edebiyat, Kur'an-1 Kerim ve Hadis'ten yalnızca manevî ilhamını almaz; hakikate bağlılık, iyilik ve güzellik gibi estetik ve sanatsal kavramlarını da elde eder.

İslami edebiyat değerlendirildiğinde, tikel bir yazarın bütün eserlerini İslami algiya bağlamak gerekmez. Hatta Hasan bin Sabit, Bûsurî, İbn-i Fârid, Rûmî, Sa'di, Hafız, Camî, Attar, Kabir, İkbal, Galib, Necib el-Kiylani, Bâkesir, Şevki, Abdülhamid Cûde es-sahhar, Hamka, Şahnun Ahmed ve Şükrü Zain gibi büyük İslami şair ve yazarların eserleri bile bunu yapmaz. Bu; Muhammed Kutub, Muhammed Kemal Hasan ve Muhammed Buharî Lubis tarafından altı çizilen mutlak bir fikirdir.

Bazı araştırmacılar İslami edebiyatın konularının İslam ile ilgili meselelerle sinırlı tutulması gerektiği görüşündedirler. Bu varsayım, İslami edebiyat İslami konularla ya da yerel çevreyle sinırlandırılamayacağ i için yanlıştır. Kuran; Ashab-1 Kehf, 'Ad, Semud ve diğerleri gibi birçok konu içerir. İslami edebiyatı tanımlayan şey konular değil yazarın bunu sunuş yoludur. Hz. Muhammed gibi İslami bir tema, Müslüman bir yazar olan

${ }_{13}$ Bünyamin Erul, "Vedâ Hutbesi", Türkiye Diyanet Vakfi İslam Ansikolopedisi (Erişim 11 Temmuz 2019). (Çevirenin notu) 
Selman Rüşdi tarafından yazılan Şeytan Ayetleri'nde olduğu gibi İslam dışı olabilirken; Kelile ve Dimne' nin ${ }^{14}$ Hintli yazarı Beydeba'nın kitabındaki “Tavşan ve Aslan" hikâyesi gibi İslami olmayan bir konu, Celaleddin Rumi'nin Mesnevi'sindeki ${ }^{15}$ "Aslan ve Vahşi Hayvanlar" hikâyesinde İslami bir konuya dönüşür. ${ }^{16}$ Yalnızca içeriğe bağlı olan herhangi bir yazı, kelimenin gerçek manasıyla edebiyat olarak ele alınamaz. Benzer bir şekilde, yalnızca şekle bağlı olan bir eser de değersizdir. Dahası, konusu olan ancak şeklen eksik yazının da içtihat, tektanrıcılık ya da teoloji metinlerinden hiçbir farkı yoktur. Bu tip yazılar edebi değil, bilimseldir.

İslami edebiyat; aşk, ölüm, kıskançlık, cömertlik, tamahkârlık, cesaret, fedakârlık, dostluk, annelik, fazilet, kötülük, dürüstlük, kahramanlık, adalet, korkusuzluk gibi evrensel ve insani değerleri telif eder. Ayrıca Hamza, Eyüp ve Hatim et-Taî gibi karakterleri içine alacak şekilde genişler.

İslami edebiyat bir dille sınırlandırılmaz, her dil her İslami yazar tarafından kullanılabilir ancak ilahi vahyin, hadisin ve İslami mirasın önemli bir parçası olduğundan günlük dua ve ibadetlerinde onu okuyacak her Müslüman için zorunlu olduğu gibi her İslami yazar için de Arap dilini bilmek zorunludur. Bu kutsal Kuran dilinde birçok uluslararası yazara ilham veren muhteşem başyapitlar yaratılmıştır. Dolayısıyla, İslami yazarlar bu eserleri okumalı ve böylelikle esinlenmeli ve bu düşüncelerinden bazılarını İslami edebiyat içinde tanıtmalıdırlar. İkbal bu durumun nedenini şöyle açıklar:

“Edebiyatta sana iyi ve hayırlı tefekkür lazımdır. Arap edebiyatına dönmen gerekir.

Gönlünü Arap Selma'sına (Arap edebiyatında sevgili ismi) ver. Ta ki sana Kürt akşamından Hicaz sabahı dolsun." ${ }^{17}$

Daha önce de bahsedildiği gibi yazar, herhangi bir dilde yazabilir. Böylece edebiyatı, evrensel İslami edebiyatı karşılayacağından Rumî, Sa'dî, Ha-

${ }_{14}$ Abdullah Ibnul Muqafa', Kilailah Wa Dimnah (Cairo: Dar Miser Lil Tiba'ah, 1977), 83-85.

${ }^{15}$ Mustafa Ghalib, Jalaluddin Al-Rumi (Cairo: 'Azi-Din Press, 1981), 50-75.

${ }^{16}$ Kelile ve Dimne'de bahsi geçen hikâye İbnül Mukaffa'nın aynı adla Türkçe' ye aktarılan çevirisinde "Aslan ve Dimne" isimli hikâyenin içinde geçen alt hikâyelerden biridir. Bk. Beydebâ, Kelile ve Dimne, çev. Said Aykut (B.y.: Şule Yayınları, 2003), 71-74. Eserin İngilizce çevirisinde ise hikâye "The Lion and the Rabbit" başlığı altında müstakil bir şekilde ele alınmıştır. İngilizce çeviri için bk. Fables of Pilpay: Revised Edition (B.y.: Riverside Press: 1872), 94-98. Tavşan ve aslana dair bu hikâye, Mesnevi'de ise "Av Hayvanlarının Aslana, Tevekkül Edip Çalışmayı Terk Etmesini Söylemeleri" başlıklı hikâyenin içinde yer alır. Bk. Mevlana, "Av Hayvanlarının Aslana, Tevekkül Edip Çalışmayı Terk Etmeyi Söylemeleri", çev. Veled İzbudak, Mesnevî̀ (İstanbul: Milli Eğitim Bakanlığı Yayınları, 1990), 72-97. (Çevirenin notu)

${ }_{17}$ Muhammed İkbal, Esrar-ı Hodi: Benliğin Sırları, çev. Ali Nihad Tarlan (B.y.: Yenilik Basımevi, 1958), 44. (Çevirenin notu) 
fız, Cami, Attar ve İkbal' in eserlerinin uluslararası dillere çevrildiği gibi tüm dünya dillerine aktarılacaktır. Müslümanlar, Kuran'ın alıntılanan ayetiyle de ilgili olarak, bir yandan Arapçanın öğrenilmesine ve öğretilmesine daha fazla dikkat göstermelidir ve aynı zamanda diğer yandan çeviriye de önem vermelidirler: "Ey insanlar! Doğrusu biz sizi bir erkekle bir dişiden yarattık. Ve birbirinizle tanışmanız için sizi kavimlere ve kabilelere ayırdık." (el-Hucurât, 49/13)

Demek ki edebiyat kendi yerel dilinden evrensel dile transfer edilebilir. İslami yazarlar kendilerini bir dille sınırlandırmamalı, birçok dil öğrenmeli, birçok dilde okumall, en azından edebi çevirileri kendi dillerinden okudukları gibi, yabancı dilde de okuyabilmelidirler. İslami yazarlar tercihen, İkbal'in Arapça yazabilmeyi ümit etmesine rağmen büyük şiirlerini Müslüman Asya'nın ortak dillerinden biri olan Farsça' da yazması gibi edebiyatlarını geniş bir okuyucu kitlesine ulaştırabilecek dilde yazarlar. Arap olmayan bir yazarın Kuran dili olan Arapça ile yazması veya en azından okuyabilmesi övülmeye değerdir.

Birçok teorisyen, İslami edebiyat yazarları için Müslüman olma durumunu şart koşar. Bu durum, teorisyenlerin ilgili ayetleri aşağıda verildiği gibi olan Şuarâ Suresi'nden kaynaklanabilir:

"Şairler(e gelince), onlara da sapıklar uyarlar. Onların her vadide başıboş dolaştıklarını ve gerçekte yapmadıkları şeyleri söylediklerini görmedin mi? Ancak iman edip iyi işler yapanlar, Allah'ı çok çok ananlar ve haksızlığa uğratıldıklarında kendilerini savunanlar başkadır. Haksızlık edenler, hangi dönüşe (hangi akıbete) döndürüleceklerini yakında bileceklerdir." (eş-Şuarâ 26/224-227)

$\mathrm{Bu}$ ayetler aslında Hasan bin Sabit gibi peygamberi ve yeni dini savunan Müslüman şairler hariç tutularak, İslam'a ve Hz. Muhammed'e saldıran inanmayanlardan bahseder. Yukarıda bahsi geçen teorisyenler bu ifadeleri geneller ve bütün şairlere uygular ve sonuç olarak yazarın inançlılığını ve Allah'ın adından bahseden ve adaletsizliği reddeden iyi eylemlerin faili olma durumunu şart koşarlar. Teorisyenlerin bu bakış açısı Müslümanların günümüzde karşılaştıkları ciddi durumların da sebebidir. Dahası, bu durum edebiyat kavramını, yazarın kendi kişiliği ve insana, hayata ve evrene dair algısının ifadesi olarak görmenin de sonucudur. Wordsworth'ün iddia ettiği gibi edebiyat, yazarın kişiliğinin ifadesi olmasa bile, Eliot'un düşündüğü gibi bundan kaçış da değildir. Edebiyat, benim fikrime göre, insanın yaşamı, yaşamdaki rolünü anlamak üzere kendisine ve diğer insanlara yardım etmek ve böylelikle Allah'ın onun için belirledi- 
ği yolda yaşayarak onu yaratılış amacına ulaştıracak insan ve evren hakikatinin keşfidir.

Yukarıda bahsedilen teorisyenler ayrıca İslami ve Müslüman terimlerini de karıştırmışlarıdır. İlk kavram ideolojiktir ve tekil yazar ile ilgilidir, dolayısıyla bireysel iması olan bir terimdir. İkinci kavram genel ve kapsamlıdır. Ayette de geçtiği üzere, itaat ve âlemlerin rabbi Allah'a teslim olma anlamına gelir: "Çünkü Rabbi ona: Müslüman ol, demiş, o da: Âlemlerin Rabbine boyun eğdim, demişti." (el-Bakara 2/131)

Eğer evrensellik kavramının İslami edebiyat teorisinin teorik temelini şekillendirmesini istiyorsak, edebiyatın yalnızca İslami yazarlar tarafından beslenmesi ve yalnızca Müslümanlara hitap etmesi kâfi değildir. Biz Müslüman olamayanlara bunun bir parçası olmaları için kapıları açmalıyı, takip etmeliyiz ve bu teoriyi onların edebi çalışmalarına uygulamayız ve hem Müslümanlara hem de Müslüman olmayanlara farksız yönelmeliyiz.

$\mathrm{Bu}$ makale yazarlara ve tikel mezheplere değil, edebiyata odaklanmamızı önerir. Bunu yaptığımız zaman, İslami edebiyat farklı ülkelerden birçok büyük uluslararası yazarın çalışmalarını da içerecektir. Tıpkı Goethe'nin Doğu-Batı Divanı antolojisinde, aşağıda verilen satırlarda görülebileceği gibi:

“Doğuda Allah'ındır. Batı da Allah'ındır. Kuzey ve Güney sahası. Sulh içindedir onun kudretiyle.

O tek Adil olan. Hak olanı istiyor herkes için. O'nun yüz isminden biri de "El-Adl". Bu yüce isim çok yüceltilsin. Âmin.

Dalâlet beni şaşırtmak ister. Sen şüphelerimi dağıtmasını bilirsin: Amellerimde ve şiirlerimde sen yoluma istikamet verirsin."18

Böyle bir edebiyat ayrıca, Tagore gibi bir şairin aşağıdaki dizelerinde görebileceğimiz tarzda eserlerini de içerebilir:

“Benim sana duam budur, Allah'ım- çarp, kalbimdeki ihtiyacın taa kökünde çarp. Bana sevinçlerimi ve üzüntülerimi kolayca kaldırabilecek gücü ver.

Bana Senin hizmetindeki aşkı değerlendirecek gücü ver.

Bana fikre saygisızlık etmeyecek ve küstah kudretin önünde diz çökmeyecek gücü ver.

${ }_{18}$ Johann Wofgang von Goethe, "Nazarlık", çev. Bayram Yılmaz, Doğu Batı Divanı (B.y.: İyi Adam Yayınları, 2000). (Çevirenin notu) 
Bana başımı her günkü gibi değersiz şeylerin üzerinde tutacak gücü ver.

Ve bana, kuvvetimi Senin emrine, aşkla feda ettirecek gücü ver."19

Herhangi bir İslami yazarın kültürü evrensel olmalıdır. Arapça ve Kur'an-1 Kerim'de temsil edildiği şekliyle İslami miras, peygamberlik geleneği ve Arap ve İslam edebiyatı hakkındaki bilgisine ek olarak İslami yazar, uluslararası edebiyat teorilerinde tecrübe sahibi olmalı ve antik ve modern büyük uluslararası yazarların edebi eserlerine dair bilgili olmalıdır. Dahası, İslami yazarın eserlerinin sanatsal öğeleri uluslararası standartlarda olmalıdır. İslami yazarlar; mesajını yaymak, Kuran ve hadisten alıntılar yapmak bakımından Hz. Muhammed'in izinden gitmelidirler. İslami yazarlar, tüm insanlıkla bir olmalı ve kendilerini etik bağ ve sınırların ötesine ve üzerine yükseltmelidirler ve bunu yaparken Kuran'ın şu ayetine odaklanmalıdırlar: " Şüphesiz bu (insanlar) bir tek ümmet olarak sizin ümmetinizdir." (el-Mü'minûn 23/52).

İslami yazarlar, ağılarından kaçan ya da kalemlerinden çıkan her kelimeden kendilerini sorumlu tutmak zorundadırlar çünkü kelimeler, sözlü veya yazılı harfler ve hecelerden ve genellikle edeb (edebiyat/literature) olarak adlandırılan şeyi yaratmaya yarayan bir araçtan, yaşamın varoluşsal zorluklarından geçici olarak kaçmaya izin veren okumalardan daha fazlasıdır. Dolayısıyla İslami yazarlara göre kelimeler, bazı dünyalar yaratabilen ve diğerlerini ortadan kaldırabilen yaratıcı güçtür. Bu nedenle, yazarlar kullanılan kelimelerin uygunluğunu tayin etmek ve haklı ya da haksız veya doğru ya da yanlış olduğunu bilmek konularında sorumludurlar. Yazarlar ayrıca merhem yerine zehir, merdiven yerine engel olmasınlar diye kelimelerin nerede söylendiği veya yazıya aktarıldığına olabildiğince dikkat etmelidirler. Kelimeler İslami yazarların kendilerine ve aynı arzuya sahip olanların ruhlarına ektikleri tohumlardır. Kelimeler yazarların kendileri için tasarladıkları ve diğerlerin yazarın hedefine yöneldiği yollardır. ${ }^{20}$

b. İslami edebiyatın özelliklerine gelince, bu özelliklerden bazıları bazı İslami olmayan edebiyatlarla uyumludur ve bazıları da özgündür. İslami edebiyatı diğer edebiyatlardan ayıran ilk özellik; insana, hayata ve evrene dair İslami algının derin anlayışından doğmuş olmasıdır. Bu özellik özgündür ve onu diğer edebiyatlardan ayırır.

\footnotetext{
${ }^{19}$ Rabindranath Tagore, Gitanjali, çev. Bülent Ecevit (Ankara: Prestij Yayın, 2011), 29. (Çevirenin notu)

${ }^{20}$ Mikhail Na'imah, Sab'un (Beirut: Darul ‘Ilm li'l-Malaiin, 1979), 677.
} 
İkinci özellik, daha önce alıntılanan Şuarâ Suresi'nin 224-227. ayetlerinde olduğu gibi İslami yazarların ilham aldıkları hakikattir. Bir diğer ilham ise birçok mesel ve peygamberin sözlerinden gelir.

İslami edebiyatın üçüncü özelliği, yazarların Allah’a karşı taşıdıkları sorumluluktur. Bu yüzden yazdıkları, onların alıntılanan ayete dair anlayışlarına dayandığı için, derin bir sorumluluk duygusunun sonucudur: “Nûn. Kaleme ve (kalem tutanların) yazdıklarına andolsun (...)" (el-Kalem 68/1).

Dördüncü özellik, iyi niyettir (salih amel/good deed). İslami yazar tarafından yaratılan edebi eserler, insanların refahını amaçlamalı ve insanlığın iyiliği için olmalıdır. Böyle bir edebi eser iyi niyetlidir ve alıntılanan ayete ve Hz. Muhammed'in hadisine uygun şekilde eserin yazarı ödüllendirilir: "(Allah) Güzel bir sözü, kökü (yerde) sabit, dalları gökte olan güzel bir ağaca (benzetti)." (el-İbrâhîm 14/24).

“İnsanoğlu öldüğü zaman, bütün amellerinin sevabı da sona erer. Şu üç şey bundan müstesnadır: Sadaka-i câriye, istifade edilen ilim, kendisine dua eden hayırlı evlat." ${ }^{21}$

Beşinci özellik, Kur'an'da taahhüt edildiği gibi, edebiyatın insanların yararı için olmasıdır: "Sizden, hayra çağıran, iyiliği emredip kötülüğü meneden bir topluluk bulunsun. İşte onlar kurtuluşa erenlerdir." (el-Âl-i İmrân 3/104).

Altıncı özellik, edebiyatın Allah rızası için olması ve ün veya şöhret aramak gibi materyalist bir amacı olmamasıdır. Alıntılanan ayetlerdeki gibi, nihai mesaj Allah'ın hoşnutluğunu gözetmek olmalıdır: "Yaratan Rabbinin adiyla oku!" (Alak 96/1).

"De ki: Şüphesiz benim namazım, kurbanım, hayatım ve ölümüm hepsi âlemlerin Rabbi Allah içindir." (el-En'âm 6/162).

Yedinci özellik, edebiyatın tabiatı gereği evrensel olmasıdır. Her yerde ve her zaman insanları ilgilendiren insani meseleleri içermeli, evrensel estetik standartlarda olmalı ve yazar tüm insanlığa yönelmelidir.

c. İslami edebiyatın mesaji; zevk, eğlence ve keyfi merkeze almaz ya da "Sanat sanat içindir" gibi bazı Batılı teorilerin özümsenmesini isteyen kimi eleştirmenlerin savunduğu şekilde yalnızca estetik unsurlara odak-

${ }^{21}$ Marican Y. Mansoor, Sayings of the Prophet (Kuala Lumpur: Orio Consultancy, ts.), 11; Muhyiddin Ebu Zekeriya Yahya b. Şeref Nevevî, Riyazü's-salîhîn: Metin ve Çeviri, çev. M. Emin Özafşar, Bünyamin Erul (Ankara: Diyanet İşleri Başkanlığı, 2013), 3: 13 (No: 1388). (Çevirenin notu) 
lanmaz. İslami edebiyatın nihai mesajı, ibadet teorisi ve tamamlayıcı teorinin iddia ettiği gibi eğitim veya kalkındırma değildir. İnsanın, hayatın ve varoluşun özünü keşiftir. İslami edebiyatın ana hedefi, kaderlerini gerçekleştirmeleri için Allah'ın emriyle tasarlanmış hayatları süresince insanlara yardım etmektir. İslami edebiyatın esas ve daimi gayesi, evrensel sistemi ve amaçlarını anlamaktır. ${ }^{22}$ Sanat, yaratıcısının ya da insanların gözünde ne kadar üstün olursa olsun, yazar ve insanlar onu, kendilerini sınırlı dünyanın prangalarından azat edip sınırsız dünyanın özgürlügüune götüren güce çevirmedikçe gerçek bir önemi yoktur. Sanat ne kadar güzel olduğunun önemi olmaksızın, eğer bize hayatın anlamını keşfetmemiz için yardım etmiyorsa ki hayatın anlamı cennet ve dünyadan daha bakidir, önemsiz bir şeydir. ${ }^{23}$ İslami mesajın bir tarafı da tüm insanların kalplerini birleştirmek ve bu kalpleri aşk, barış, dinginlik ve neşe ile doldurmaktır. Böylece tüm bu kalpler dünya ile bir olacaklar ve dünya da onlarla bir olacaktır. Bu sayede, bu bütünlük güzellikle içkinleşerek daimi kalacak ve yok olmayacaktır. ${ }^{24}$ Diğer bir tabirle, İslami edebiyat, İslam'ın kendi mesajını taşır ve tüm insanlığ 1 ilgilendiren ana hedefi ile insanlığa yönelmektedir.

\section{3. İSLAMİ EDEBIYYATTA EVRENSELLİK}

Attar, Hafız, Sa'di ve Rûmî gibi büyük, antik İslami yazarlar dikkatlerini evrensellik kavramına vermişlerdir ve Rumi'nin aşağıdaki dizelerinde de görebileceğimiz gibi çalışmalarında bunu güzel bir şekilde örneklerler:

“Dünyanın gizli sırlarını bağışlayan derviş, bir eli açık padişah gibidir.

Her an karşılıksız bedava bir mülk ihsan eder.

Ekmek dilenen kişi derviş değildir.

Derviş can bağışlayan, hayat veren bir kişidir." 25

Evrensellik kavramını, seçkin bir şair ve filozof olan Muhammed İkbal gibi büyük modern yazarların bazı eserlerinde de buluruz. Örneğin şair, Esrar ve Rumuz'da şöyle der:

“ Biz ki vatan ile mukayyet değiliz. Bakış gibi iki gözün nuruyuz; fakat biriz.

\footnotetext{
${ }^{22} \mathrm{Na}^{\prime} \mathrm{imah}, \mathrm{Sab}^{\prime} u n, 666$.

${ }^{23} \mathrm{Na}^{\prime} \mathrm{imah}, \mathrm{Sabûn}, 718$.

${ }^{24} \mathrm{Na}^{\prime}$ imah, Sab'un, 705.

${ }^{25}$ Şefik Can, “ 654 nolu rubai,” Hz. Mevlânâ'nın Rubaileri (Ankara: T.C. Kültür Bakanlığı Yayınları, 1991).
} 
Hicazlı, Çinli ve İranlıyız. Fakat aynı neşeli sabahın çiğ danesiyiz."26

Ve Rumuz-i Bîhodî'de şöyle der:

"Aşk adamı isen nesep düşüncesinden geçmen lazımdır.

Şu İranlıdır, bu Arap'tır demeyeceksin." ${ }^{27}$

İkbal'in evrensellik kavramı bazı şiirlerinde de bulunur. Örneğin, Esrar ve Rumuz'da, Hicaz Armağanı'nda ve tüm insanlığa hitap ettiği için sesinin evrenselliğe dair daha yüksek ve net çıktığı Musa Vuruşu'nda bunu bulabiliriz:

“Ben ne İranlıyım ne Hintli ne Iraklı ne de Hicazlı

Benlikle öğrendim iki cihandan bağımsız kalmayı" ${ }^{28}$

Antolojisi Rumuz-ı Bîhodî́de, İkbal evrensellik idealini daha net ve daha sık sergiler:

"Müslümanın fıtratı baştan ayağı şefkattir. Dünyada onun elinden ve dilinden iyilik etmek ve acımaktan başka bir şey gelmemelidir." ${ }^{29}$

"Eğer bir nağmen varsa yalnız başına terennüm etme. Bizim bahçemizin dalından başka bir yerde ötme."

"Kendine Türk, Afgan adını vermişsin. Yazık sana ki olduğun yerde kalmışsın; bir adım ileri gidememişsin.

Müsemmayı isimden kurtar. Kadehlerden geç, küp ile meşgul ol.

Ey sen ki bir ad yüzünden rezil ü rüsva olmuşsun. Aynı şeye ayrı ayrı ad vererek, onları birbirinden tefrik ederek ham bir fikre kapılmışsın." ${ }^{31}$

“Müslümansan Hak'tan gayrıya muhtaç olma, Dünya insanları için baştan aşağı hayır ol." ${ }^{32}$

“Biz Rum ve Arap’a bağlı değiliz. Bizi birbirimizi bağlayan soy sop rabıtası değildir." ${ }^{33}$

Maalesef henüz bu muhteşem ve yüce ezgi; mühim mesajını Hindistanlı, Pakistanlı, Arap, Afgan ve İranlı halklara yöneltmekle meşgul

${ }_{26}$ İkbal, Esrar-ı Hodî: Benliğin Sırları, 34. (Çevirenin notu)

${ }^{27}$ Muhammed İkbal, Rumuz-ı Bîhodî: Benlikten Geçmenin Remizleri, çev. Ali Nihad Tarlan (B.y.: Yenilik Basımevi, 1958), 56. (Çevirenin notu)

${ }^{28}$ Muhammed İkbal, "Gazel," Musa Vuruşu\& Hicaz Armağanı, çev. Celal Soydan (İstanbul: Hece Yayınları, 2013), 99. (Çevirenin notu)

29 İkbal, Rumuz-ı Bîhodî: Benlikten Geçmenin Remizleri, 38. (Çevirenin notu)

${ }^{30}$ İkbal, Rumuz-ı Bîhodî: Benlikten Geçmenin Remizleri, 38. (Çevirenin notu)

${ }^{31}$ İkbal, Rumuz-ı Bîhodî: Benlikten Geçmenin Remizleri, 52. (Çevirenin notu)

${ }^{32}$ İkbal, Rumuz-ı Bîhodî: Benlikten Geçmenin Remizleri, 53. (Çevirenin notu)

33 İkbal, Rumuz-ı Bîhodî: Benlikten Geçmenin Remizleri, 56. (Çevirenin notu) 
olduğu için Ikbal'in bütün şiirine yayılmadı. Başka bir deyişle İkbal, hayatını ve şiirini genel anlamda Doğu halklarına, özel anlamda ise İslam ümmetine adadı. İslami yazar tabii ki İslam ümmeti ile ilgili meselelerle alakadar olmalıdır. Ancak kendini Müslümanlarla sinırlandırıp insanlığın diğer milletlerini ve kavimlerini yok saymamalıdır. İslam' 1 kendine rehber edinmeli ve onun elçisinin izinden gitmelidir. Edebiyatını tüm insanlara, Müslümanlara ve Müslüman olmayanlara hep birlikte yöneltmelidir. Böylece evrensel bir yazar olur ve edebiyatı da kelimenin gerçek manasıyla evrensel bir edebiyat olur.

\section{SONUÇ}

Evrensellik teorisi, Âlemlerin Rabbinin okuma yazma bilmeyen Hz. Muhammed'e vahyettiği ve tüm insanlık için bir merhamet ve ikaz olan Kur'an-1 Kerim'den ilham alır. Kuran-1 Kerim, İslam'ın özünü, insanların içinde Allah tarafından yaratılan doğal bir eğilim olarak yansıtır ve tüm yaratılanlara hitap eden evrensel mesajı dile getirir. Evrensellik teorisi, İslami edebiyatın yalnızca insan, yaşam ve evrene dair İslami algıdan değil, aynı zamanda Kuran'da, sünnette ve İslami estetikte örneklendirilen edebiyat kavramından da kaynak aldığını kabul eder.

Bu teori yalnızca yeni İslami edebiyat kavramını sunmaz, aynı zamanda yazmayı hakikat ve güzelliğe dayanan ulvî bir mesajı sunan kutsal bir meslek olarak çizer. Böyle bir yazma eylemi, insanlığın refahını amaçlar ve bu sebeple yazar hem bu hayatta hem de ahirette ödüllendirilir. Bu teori aynı zamanda edebiyatın, yazarın insanlığa hizmet ile görevlendirildiği için Allah'a şükretmesini gerektiren Allah'tan bir hediye olduğunu düşünür. Bu teori, edebiyatın temel fonksiyonunun insanın, hayatın, varoluşun ve evrenin özünü keşfetmek olduğunun altını çizer. İslami edebiyatın nihai mesajı, kaderini Allah'ın çizdiği yolda yaşaması için insana yardım etmektir. Evrensellik teorisi, İslami edebiyatın mesajının İslam'la aynı olduğunu savunur, her ikisi de evrensel, kutsal ve kapsamlıdir.

Diğer İslami teorilerin aksine evrensellik teorisi, İslami edebiyatın kapsamını genişletir, Müslüman olmayan yazarların eserleri için iyi İslami düşünce ve fikirlerden oluşan bir oda açar. Aynı zamanda İslami yazarların ufuk ve akıllarını genişletir, onların kapsamlı düşünmelerini ve tüm mekân ve tüm zamanlardaki bütün insanlar için yazmalarını bekler. Bu teori, yazarın ne Batı'nın ne de Doğu'nun insanlarına mesaj vermesini s1nırlandırır dolayısıyla yazarlar Batı'ya karşı Doğu'yu uyarmayacak ya da Doğu'ya karşı Batı'yı desteklemeyecektir. Tersine yazarlar onları birleştir- 
meli ve hepsine bir millet olarak hitap etmelidirler; çünkü çatışma sesleri Doğu'yu Batı'dan nefret ettirir ve Batı'yı da Doğu'nun bilgeliğine ve edebiyatlarına dair sağırlaştırır.

Bu teori, yazarların standartlarını yükseltir ve diğer uluslararası yazarların arasında eşit olabilmelerini sağlayacak sanatsal yeteneklerini genişletir.

Özetle, bu teori İslami edebiyatın yayılmasında etkili olur, okuyucu sayısını arttırır, konumunu yükseltir ve diğer edebiyatlardan etkilenen İslami yazarın hâlihazırdaki rolünü değiştirerek diğer edebiyatların yazarlarının onları aradığı ve eserlerine imrendiği, İslami yazarların daha etkili olduğu yeni bir rol kurar. Bu yolla İslami edebiyat; İslam'ın mesajını, değerini ve düşüncelerini tüm dünyaya yayabilir.

\section{KAYNAKÇA}

Ali, Abdullah Yusuf. The Meaning of the Holy Qur'an. Kuala Lumpur: Islamic Book Trust, 2006.

Beydebâ. Kelile ve Dimne. Çev. Said Aykut. İstanbul: Şule Yayınları, 2003.

Beydebâ. Fables of Pilpay: Revised Edition. Cambridge: Riverside Press. 1872.

Cleary, Thomas. The Wisdom of the Prophet: Sayings of Muhammad. Baston: Shambhala Publications, 2001.

Erul, Bünyamin. "Veda Hutbesi”. Türkiye Diyanet Vakfı İslam Ansikolopedisi. Erişim 30 Ağustos 2019. https://islamansiklopedisi.org.tr/veda-hutbesi

Ghalib, Mustafa. Jalaluddin Al-Rumi. Cairo: 'Azid-Din Press, 1982.

Goethe, Johann Wolfgang von. Goethe: Selected Verse. Ed. David Luke. Middlesex: Penguin Classic, 1987.

Goethe, Johann Wolfgang von. Doğu Batı Divanı. Çev. Bayram Yılmaz. B.y.: İyi Adam Yayınları. 2000. https://yadi.sk/i/jN2jnYI43GYRai

Hilal, Muhammad Ghunaimi. Al-Adab Al-Muqarn. Beirut: Dar Al-Audah, 1987. İbnü'l-Mukaffa', Abdullah. Kilailah wa Dimnah. Cairo: Dar Miser Lil Tiba'ah, 1977.

İkbal, Muhammed. Rumuz-i Bekhudi. Çev. A. R. Tarik. Lahore: Islamic Book Service, 1977.

İkbal, Muhammed. Asrar-i Khudi. Çev. A. R. Tarik. Lahore: Islamic Book Service, 1977.

İkbal, Muhammed. The Rod of Moses: Versified English Translation of Iqbal's Zarb-i Kalim. Çev. Sayed Akbar Ali Shah. Lahore: İkbal Academy, 1983.

İkbal, Muhammed. Esrar-ı Hodi: Benliğin Sırları. Çev. Ali Nihad Tarlan. B.y.: Yenilik Basımevi. 1958. https://archive.org/details/Esrar-HodBenliinSrlarRumuzuBhodBenlikdenGemeninRemizleri-kbalAliNihadTarlan

İkbal, Muhammed. Rumuz-ı Bîhodî: Benlikten Geçmenin Remizleri. Çev. Ali Nihad Tarlan. B.y.: Yenilik Basımevi. 1958. https://archive.org/details/Esrar-HodBenliinSrlarRumuz-uBhodBenlikdenGemeninRemizleri-kbalAliNihadTarlan

İkbal, Muhammed. Musa Vuruşu\& Hicaz Armağanı. Çev. Celal Soydan. İstanbul: Hece Yayınları. 2013. 
Marican, Y. Manssoor. Sayings of the Prophet. Kuala Lumpur: Orina Consultancy. ts. Kur'an-ı Kerim Meâli. Erişim: 30 Ağustos 2019. https://kuran.diyanet.gov.tr/mushaf Mevlana. Mesnevi. Çev. Veled İzbudak. İstanbul: Milli Eğitim Bakanlığı Yayınları. 1990.

Nadavi, Abul Hassan. Rawa' Iqbal. Damascus: Darul Fikr, 1970.

Na'imah, Mikhaiel. Sab'un. Beirut: Darul 'ilm Lil Malaiin, 1979.

Nevevî, Muhyiddin Ebu Zekeriya Yahya b. Şeref. Riyazü's-salîhîn. Çev. M. Emin Özafşar, Bünyamin Erul. Ankara: Diyanet İşleri Başkanlı̆̆ı, 2013.

Osman, Rahmah BT Ahmad v.dğr. Al-Islam Wal Adab Al-Malayui: Tahlil Lil Niqashat Fi Malysia. Kuala Lumpur: IIUM Press, 2008.

Rumi, Jallaluddin. The Rumi Collection. Ed. Kabir Heleminski. Baston: Shambhala Publications, 2000.

Sarı, Mevlüt. El-Mevârid: Arapça Türkçe Lügât, İstanbul: Bahar Yayınları. 1980.

Şefik Can. Hz Mevlâna'nın Rubaileri. Ankara: T.C. Kültür Bakanlığı Yayınları. 1991.

Sartre, E, Jean Paul. Edebiyat Nedir? Çev. Bertan Onaran. İstanbul: Can Yayınları. 2005.

Tagore, Rabindranath. Gitanjali. New Delhi: Rupa \& Co., 2002.

Tagore, Rabindranath. Gitanjali. Çev. Bülent Ecevit. Ankara: y.y., 2011.

Uçar, Aslı. 1950ler Türkiye'sinde Edebiyat Dergiciliği: Poetikalar ve Politikalar. Yüksek Lisans Tezi, Bilkent Üniversitesi, 2007. http://www.thesis.bilkent.edu. tr/0003306.pdf 